\title{
INTRACEREBRAL HEMORRHAGE IN A CASE OF ANTIPHOSPHOLIPID ANTIBODY SYNDROME
}

\author{
Sultan ÇAĞIRICI*, Abdulkadir KOÇER**, Levent GÜL*, Ülkü TÜRK BÖRÜ*, Talip ASÍL** \\ *Dr. Lütfü Kırdar Kartal Education Hospital, İSTANBUL \\ **Bezmialem Vakıf University Medical Faculty Neurology Department, İSTANBUL
}

\begin{abstract}
BACKGROUND AND PURPOSE: The patients with lupus anticoagulants may have an increased risk for the development of ischemic brain lesions and subdural hematoma in the presence of other known risk factors. There are lots of reports related to antiphospholipid syndrome with subdural hematoma, but intra-axial bleeding is a rare complication.

CASE DESCRIPTION: We report a 37-year-old man with ptosis, central typed facial palsy, hemiparesis on the right side and motor aphasia. A CT scan and MRI showed a large cerebral hematoma located in the left fronto-parietal region and other foci of hemorrhage on the right hemisphere. Only persistently abnormal finding in laboratory studies was positive for antiphospholipid antibodies. Based on above findings we concluded that anti-phospholipid antibodies have resulted in intracerebral hemorrhage.

CONCLUSION: In the present case, we report and point that hemorrhagic complication in young patients with antiphospholipid antibody syndrome associated with fragility of the vessels and/or platelet dysfunction is another and rare cause of intracerebral bleeding.
\end{abstract}

Key Words: Antiphospholipid syndrome, intracerebral bleeding, risk factor.

\section{ANTIFOSFOLIPIT ANTIKOR SENDROMLU HASTADA İNTRASEREBRAL HEMORAJI}

\section{ÖZET}

GİRIŞ: Lupus antikoagulanı pozitif olan hastalarda digger bilinen risk faktörleri ile birlikte iskemik beyin lezyonları ve subdural hematom sıklığı artmıştır. Subdural hematom ile antifosfolipid sendrom birlikteliğini tanımlayan pek çok yazı bulunmaktadır ancak intraaksiyal kanamalar antifosfolipid antikor sendromunun nadir görülen bir komplikasyonudur.

OLGU: Bu yazıda sağ santral fasial parezi, sağ hemiparezi, motor afazi ve ptoz ile başvuran 37 yaşında erkek hastayı sunduk. BT ve MRI sol frontoparietal bölgede geniş intraserebral kanama ve sağ hemisferde küçük hemoraji odaklarını göstermekteydi. Tek pozitif labaratuar bulgusu antifosfolipid antikorların pozitif olması idi. Mevcut bulgularla hastanın antifosfolipit antikorlarla ilişkili intraserebral hematom olarak düşündük

TARTIŞMA: Bu olgu sunumunda genç bir hastada antifosfolipit antikorlarla ilişkili olarak damar frajilitesinin artması veya trombosit disfonksiyonuna bağlı nadir görülen bir durum olan intraserebral hematom olgusunu bildirdik.

Anahtar Sözcükler: Antifosfolipid antikor sendromu, intraserebral hematom, risk faktörleri.

\section{INTRODUCTION}

In the present case, we report and point that hemorrhagic complication in young patients with anti-phospholipid antibody syndrome associated with fragility of the vessels and/or platelet dysfunction is another and rare cause of intracerebral bleeding.

The antiphospholipid syndrome (APS) may be associated with recurrent abortions and thrombotic cerebrovascular events (1-6). Antiphospholipid antibody is an independent risk factor for stroke in especially young women (7).
The lupus anticoagulant (LA) is an antibody, either immunoglobulin (Ig) $M$, IgG, or both, that cross-reacts with an anionic phospholipids and beta 2-glycoprotein $\mathrm{I}$, and is usually recognized by a prolonged activated partial prothrombin time (5). Migraine type headache, ischemic stroke related to thrombosis and occlusive retinal artery pathologies are the most commonly seen clinical findings in APS. Patients with lupus anticoagulants do not typically have a bleeding tendency. A deficiency of plasma prothrombin (factor II) below 20\% of

Correspondence to: Talip ASİL Bezmialem Vakif University Medical Faculty Neurology Department, İstanbul 
normal, thrombocytopenia, uremia, and anticoagulation are the most common causes of patients with LA (5). In the present article, we report a case of intracerebral hemorhage in a patient with LA, IgM anticardiolipin antibodies, and no other associated abnormalities.

\section{CASE REPORT}

We report a 37-year-old man with antiphospholipid antibody syndrome complicated by cerebral hemorrhage. He was brought to our hospital with sudden onset of weakness of right extremities and difficulty in speech. He denied a history of trauma and was not taking anticoagulant or antiplatelet medication. He had no personal or family history of a bleeding disorder. In neurological examination, we have seen that he had ptosis, central typed facial palsy, hemiparesis on the right and motor aphasia. Babinsk's sign was positive on the left. Blood pressure with 130/80 mmHg and pulse with 78 per minute were normal. A CT scan and MRI showed a large cerebral hematoma located in the left fronto-parietal region and other foci of hemorrhage on the right hemisphere (Fig.1 \& 2).

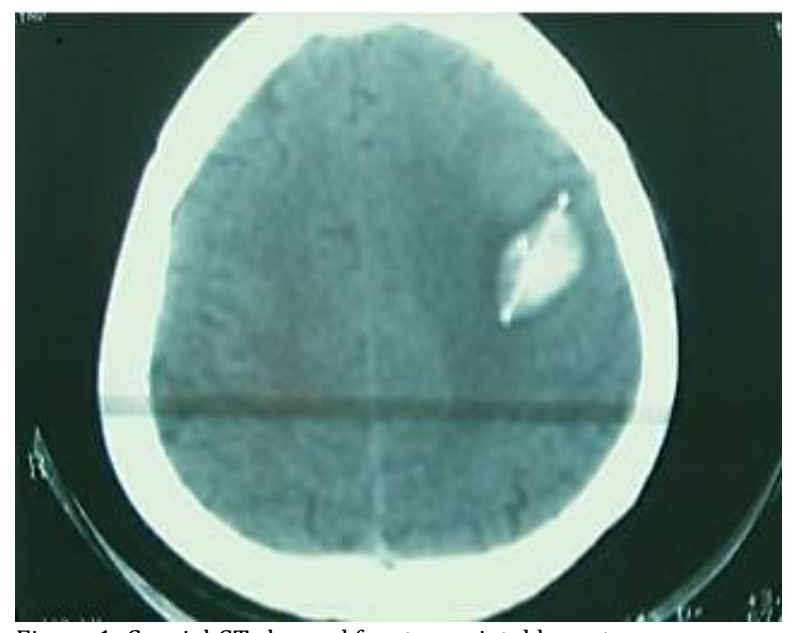

Figure.1: Cranial CT showed fronto-parietal hematoma.

MRI and conventional cerebral angiographies did not reveal any abnormality regarding an etiology i.e. vasculitis, aneurysms, arteriovenous malformations. Only persistently abnormal finding in laboratory studies was positive for lupus anticoagulant and anticardiolipin antibody, namely anti-phospholipid antibodies. The IgM anticardiolipin antibody was $16.5 \mathrm{MPL} / \mathrm{ml}$ (normal,

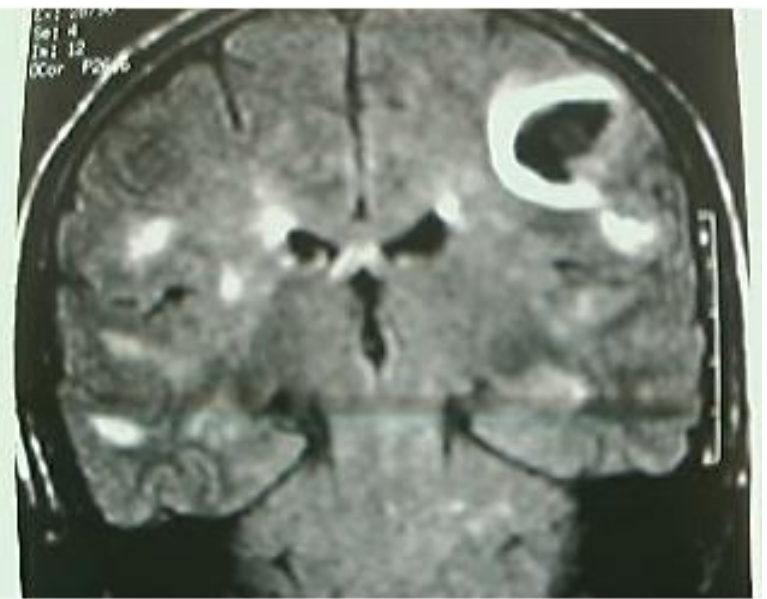

Figure.2: Cranial MRI revealed intraaxial hematoma on the left fronto-parietal region.

$<10 \mathrm{MPL} / \mathrm{ml}$ ) and IgG anticardiolipin antibody was $21 \mathrm{GPL} / \mathrm{ml}$ (normal, $10 \mathrm{GPL} / \mathrm{ml}$ ). Serum protein electrophoresis showed IgM kappa with normal polyclonal globulins. The activated partial thromboplastin time which is more important in screening and the prothrombin time were normal.

The thrombin time, fibrinogen level, bleeding time, and platelet aggregation assays, were normal. There was no serological evidence of SLE or other autoimmune diseases. He had a history of migraines. Based on above findings we concluded that antiphospholipid antibodies have resulted in cerebral hemorrhage in this young and normotensive patient.

\section{DISCUSSION}

Bleeding is very rare in patients with LA in the absence of associated hemostatic abnormalities as factor II deficiency, thrombocytopenia, or vascular defect (6). However, a few reports of APS with hemorrhagic complications in the absence of known risk factors for bleeding have been published, raising the question of an etiologic connection between lupus anticoagulants and certain types of hemorrhage $(1,2,3)$ The tendency of patients to bleed may have been due to antiphospholipid antibodies, attacking the platelet membranes and that the bridging veins in the subdural space may be the site at which the bleeding tendency easily appears $(1,2)$. A retrospective study to determine whether patients with lupus anticoagulants may have an increased risk for the development of subdural hematoma 
reported that presence of a lupus anticoagulant by itself was associated with an increased incidence of non-traumatic subdural hematoma in the presence of other known risk factors e.g. thrombocytopenia, hypoprothrombinemia, intracerebral venous hemorrhage, warfarin therapy, and advanced age with a history of a fall (3). In the present case, there was no prothrombin deficiency, thrombocytopenia, uremia, acquired von Willebrand disease, detectable platelet defect, abnormality of fibrinogen, and other known risk factors. Although lots of reports related to APS sign to subdural hematoma, intra-axial bleeding is a rare complication $(6,8)$. We report and point that hemorrhagic complication in young patients with anti-phospholipid antibody syndrome associated with fragility of the vessels and/or platelet dysfunction is another and rare cause of intracerebral bleeding.

\section{REFERENCES}

1- Muraoka I, Adachi N, Ogashiwa M, et al. Cerebral hemorrhage in a case of antiphospholipid antibody syndrome. No To Shinkei 1993;45:263-6.

2- Ohnishi M, Tokuda T, Hashimoto T, et al. A case of antiphospholipid antibody syndrome associated with subdural hematoma. Rinsho Shinkeigaku 1991;31: 1135-9.

3- Moll S, McCloud M, Ortel TL.Subdural hematoma and lupus anticoagulants. Stroke 1997 ; 28: 646-8.

4- Owaidah TM, Qurashi FH, Al Nounou RM, et al. Single center review of clinicopathological characterization in 77 patients with positive lupus anticoagulant antibodies. Hematology 2003;8:249-57.

5- Feinstein DI: Immune coagulation disorders. In Colman RW, Hirsh J, Marder VJ, Salzman EW, eds. Hemostasis and Thrombosis: Basic Principles and Clinical Practice, Ed 3. Philadelphia: J.B. Lippincott Company, 1994, pp 881-905.

6- Wynn SS, Rabinowitz I, Essex D.Bleeding in a patient with lupus anticoagulant without associated hemostatic abnormalities.Am J Hematol 1998;59:258-9.

7- Brey RL, Stallworth CL, McGlasson DL, et al. Antiphospholipid antibodies and stroke in young women.Stroke 2002;33:2396400. Comment in: Stroke 2002;33:2400-1.

8- Abouzahir A, Bourazza A, Rafik R, et al. Sneddon's syndrome: 4 cases and a review of the literature.Rev Neurol (Paris) 2003;159:1156-62. 